\title{
Interaction of various flow systems in small alpine catchments: conceptual model of the upper Gurk Valley aquifer, Carinthia, Austria
}

\author{
Sylke Hilberg $^{1} \cdot$ Franz Riepler $^{2}$
}

Received: 1 October 2015 / Accepted: 8 March 2016/Published online: 28 March 2016

(C) The Author(s) 2016. This article is published with open access at Springerlink.com

\begin{abstract}
Small alpine valleys usually show a heterogeneous hydraulic situation. Recurring landslides create temporal barriers for the surface runoff. As a result of these postglacial processes, temporal lakes form, and thus lacustrine finegrained sedimentation intercalates with alluvial coarsegrained layers. A sequence of alluvial sediments (confined and thus well protected aquifers) and lacustrine sediments (aquitards) is characteristic for such an environment. The hydrogeological situation of fractured hard-rock aquifers in the framing mountain ranges is characterized by superficially high hydraulic conductivities as the result of tectonic processes, deglaciation and postglacial weathering. Fracture permeability and high hydraulic gradients in small-scaled alpine catchments result in the interaction of various flow systems in various kinds of aquifers. Spatial restrictions and conflicts between the current land use and the requirements of drinkingwater protection represent a special challenge for water resource management in usually densely populated small alpine valleys. The presented case study describes hydrogeological investigations within the small alpine valley of the upper Gurktal (Upper Carinthia, Austria) and the adjacent Höllenberg Massif (1,772 $\mathrm{m}$ above sea level). Hydrogeological mapping, drilling, and hydrochemical and stable isotope analyses of springs and groundwater were conducted to identify a sustainable drinking-water supply for
\end{abstract}

Sylke Hilberg

sylke.hilberg@sbg.ac.at

1 Department of Geography and Geology, University of Salzburg, Hellbrunnerstraße 34, 5020 Salzburg, Austria

2 GWU Geologie Wasser Umwelt GmbH, Bayerhamerstr. 57, 5020 Salzburg, Austria approximately 1,500 inhabitants. The results contribute to a conceptual hydrogeological model with three interacting flow systems. The local and the intermediate flow systems are assigned to the catchment of the Höllenberg Massif, whereas the regional flow system refers to the bordering Gurktal Alps to the north and provides an appropriate drinking water reservoir.

Keywords Alpine valleys $\cdot$ Fractured rocks $\cdot$ Flow system concept $\cdot$ Stable isotopes $\cdot$ Austria

\section{Introduction}

Groundwater circulation within the earth's crust generally occurs at different scales: local, intermediate and regional flow systems (Toth 1999). In the small-scale structured environment of mountain catchments, springs or groundwater wells that drain different flow systems can occur in close contact to each other (Hilberg and Kreuzer 2013). Groundwater flow in alpine valleys occurs in two completely different but possibly interacting kinds of aquifers (Welch and Allen 2012). Usually, unconsolidated sediments in the valley floor provide porous aquifers. Their hydrogeological characteristics are controlled by the grain size distribution and the mineralogy of the sedimentary layers. While the mineralogy of the unconsolidated rocks is directly connected to the provenance of the sediments, the transport conditions and the conditions of sedimentation are responsible for grain size distribution, grain shape and compactness as important factors to control hydraulic conductivity. Transport conditions and sedimentation processes can vary strongly over space and time. Thick layers of coarsegrained (gravel and sand) alluvial sediments fill the glacially overdeepened alpine valleys. Postglacial landslides are a consequence of pressure release after deglaciation (Preusser et al. 
2010). Particularly in narrow alpine valleys such as the presented upper Gurk Valley, these landslides create temporal barriers for the surface runoff. In the resulting temporal lakes, lacustrine sedimentation takes place and leads to the development of fine-grained (silt and clay) layers. Changing conditions with sequences of alluvial and lacustrine sedimentation lead to a heterogenous internal structure of the sedimentary valley fill (Preusser et al. 2010; Bleibinhaus and Hilberg 2012; Salcher et al. 2012) with strong influences on the aquifer structure and the groundwater flow dynamics within the valley floor.

Valleys are framed by mountains, which normally consist of hard rocks. These hard rocks provide the second type of groundwater bodies in alpine environments and can occur as karstic or fractured aquifers. Since the presented study deals with non-karstifiable fractured rocks the karst aquifers will not be discussed further here. Basically, the hydraulic properties of fractured hard rocks are related to the network of features, namely fractures and faults (Boutt et al. 2010) as well as their petrological and geochemical properties that control the state of weathering of the rock material. Lachassagne et al. (2011) consider weathering as the most important process to provide permeability in plutonic or metamorphic hard rocks in tectonically stable regions such as ancient cratons. Groundwater flow in hard rocks is also known from various recent studies in mountain ranges (e.g. Kosugi et al. 2011; Salve et al. 2012; Gabrielli et al. 2012). Welch and Allen (2014) developed a conceptual model to describe a mountainous crystalline hard rock aquifer. They defined several layers beginning with the soil layer on the surface, underlain by a saprolite layer, a layer of fractured hard rocks, and finally the unweathered and nearly impermeable hard rock that acts as an aquitard. The thickness of the layers is strongly correlated with factors such as predeveloped tectonic structures and chemical properties of the lithology. In glacially overdeepened alpine valleys, the process of pressure release due to deglaciation (Reitner et al. 1993) is a further driving force for superficial permeability of hard rocks.

Groundwater flow is mainly driven by gravity in this system. Thus, flow occurs more or less parallel to the slope within the weathered or bulked layers in mountain catchments. Groundwater recharge and discharge are related to fractures, layer boundaries or fault zones in the more or less weathered parts of the rock massif. Springs emerge when groundwater accumulates along boundaries between permeable and less permeable units. Finally the water (as ground- or surface water) enters the alluvial and superficial sediments in the valley floor and provides groundwater recharge for the porous aquifer.

This general conceptual hydrogeological model can be transferred to various hard rock environments in the Alps and comparable alpine mountain ranges worldwide. Additionally, as mentioned in the opening statement, it can be applied to various scales. Flow systems of various scales may interact or influence each other, particularly in smallscaled alpine environments.

From the water policy perspective, spatial restrictions in small alpine valleys can create conflicts between agricultural use, settlements, and industrial requirements as well as tourism (including the production of artificial snow) and infrastructural facilities on the one hand and the protection of groundwater resources on the other. Moreover, the accessibility of potentially usable springs in high mountain regions is restricted due to steep slopes and difficult terrain. Thus, although the mountain regions are normally well supplied with precipitation and groundwater recharge (Viviroli et al. 2007) the implementation of sustainable drinking-water supply in mountain settlements represent a particular challenge (Boutt et al. 2010).

In the light of the user conflicts, an important task for alpine hydrogeologists is the optimisation of water protection zones through the identification of the actual recharge areas and the internal flow dynamics. Therefore, knowledge about interacting flow systems and the assignment of springs to various flow paths or catchments is crucial for a sustainable water supply (Hilberg et al. 2013). The present case study from the upper Gurk Valley on the southern slope of the Austrian Eastern Alps is an example for the hydrogeological complexity of small alpine valleys and how this complexity can provide possibilities for sustainable and well protected drinking-water supply sources under difficult conditions.

\section{Study site}

The present study was conducted in the southern part of the Eastern Alps in the upper Gurk Valley in Carinthia, Austria (Fig. 1a) and comprises hydrogeological investigations covering the approximately $8 \mathrm{~km}^{2}$ Höllenberg Mountain Massif and the adjacent Gurk Valley floor (Fig. 1b). The overall purpose of the study was to investigate the hydrogeological conditions in the vicinity of a popular tourist destination and community with approximately 1,500 permanent inhabitants. The task was to implement a supplemental drinking water supply that delivers at least $5 \mathrm{l} / \mathrm{s}$ within an alpine valley and surrounding hillslopes which are subjected to forestry and agricultural use.

The topographic catchment area of the Höllenberg reaches an altitude of 1,772 $\mathrm{m}$ above sea level (asl). The valley floor lies at an altitude of approximately $1,040 \mathrm{~m}$ asl. The main

Fig. 1 a Location and $\mathbf{b}$ overview of the study area in the southern part of the Austrian Alps digital elevation model derived from KAGIS (Carinthian Governmental Administration 2015). c Hydrogeological map and sampling points. d Detail of the valley floor with boreholes, springs and the River Gurk; the dashed north-south trending line marks the cross section documented in Fig. 9b 


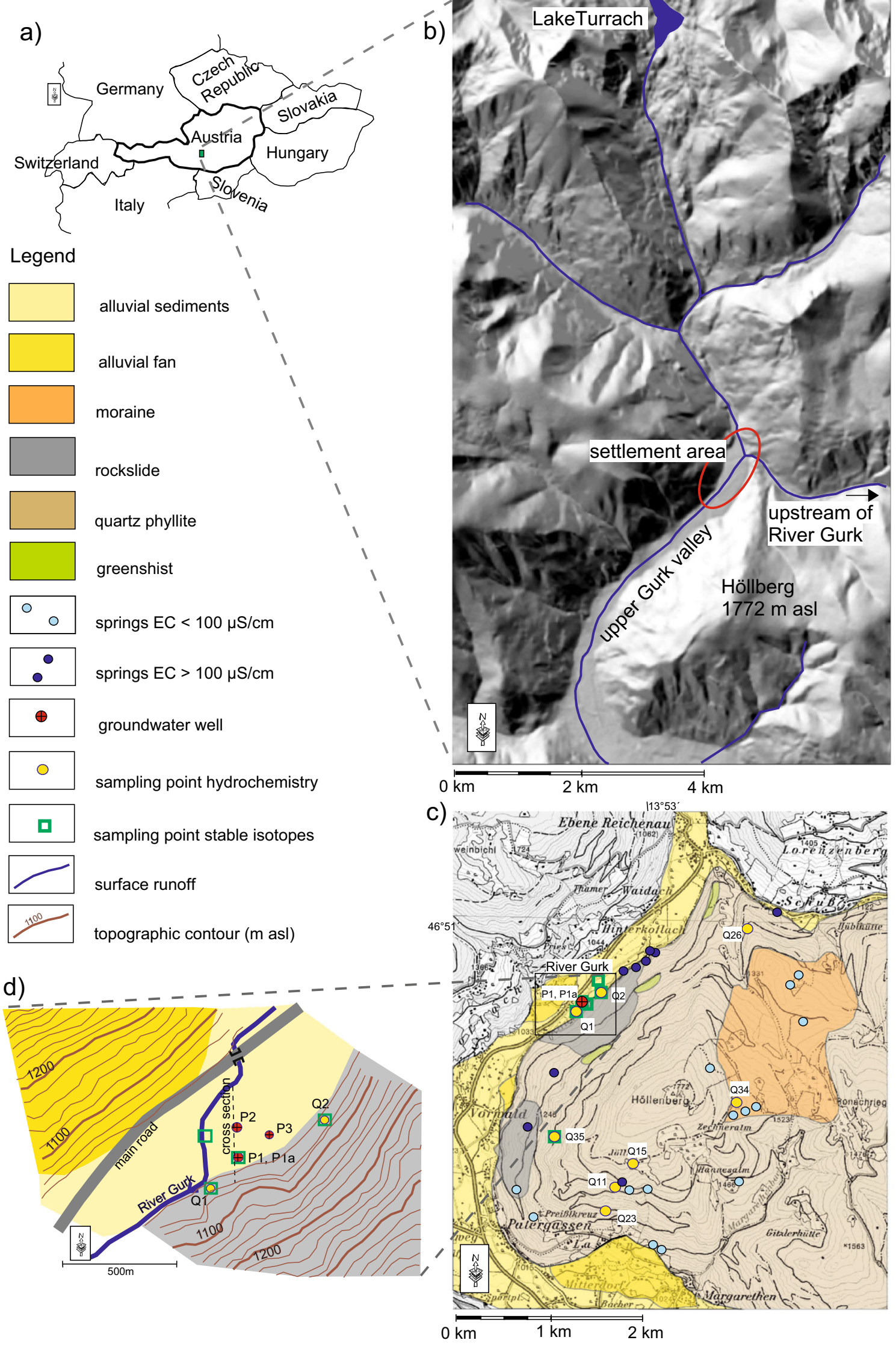


drainage of the valley and its adjacent mountain area is the River Gurk which originates approximately $10 \mathrm{~km} \mathrm{NE}$ of the study area and passes the Höllenberg Massif on its northern and western slope. The mean discharge of the River Gurk is in the range of at most $1 \mathrm{~m}^{3} / \mathrm{s}$. The rather narrow alpine valley is less than $500 \mathrm{~m}$ wide in the study area. The Höllenberg is part of the eastern alpine Gurktal Nappe Complex which is mainly built up of paleozoic low metamorphic quartz phyllites, volcanic rocks, carbonates, shales, conglomerates and red beds (Rantitsch 2001). In the range of the Höllenberg Massif itself, only quartz phyllites with a few inclusions of green schists are observed.

\section{Methods}

\section{Hydrogeological field work}

Three boreholes (P1, P2 and P3 shown in Fig. 1d) were drilled in autumn 2008 to investigate the porous aquifer and understand the flow conditions in the Gurk Valley and to gain information about the interactions between the fractured hard rock aquifer in the catchment, the porous aquifer in the valley floor, and the surface-water body. The drilling sites were situated between the north-western foot of the Höllenberg Massif and the Gurk riverbank. The $40 \mathrm{~m}$ deep borehole $\mathrm{P} 1$ and the $20 \mathrm{~m}$ deep boreholes P2 and P3 (Fig. 1d) were developed as groundwater observation wells for long-term monitoring of the porous aquifer. Since two aquifer levels were unexpectedly detected during the drilling (see 'Results and discussion'), two wells, each tapping one of the aquifer levels, were implemented at each drilling site. The drillings were documented in borehole logs (shown for P1 in Fig. 2).

Extensive and detailed hydrogeological mapping of the Höllenberg Massif was conducted in summer 2011. It involved the spatial documentation of hard rock outcrops and their structural geological setting as well as the weathered and unconsolidated cover of the phyllitic hard rock. The phyllite outcrops were classified with regard to their stage of weathering as either unweathered or weathered phyllites. Due to the homogeneous lithological constitution of the Höllenberg Massif, further geological differentiations were not possible and also not necessary with regard to their hydrogeological properties.

Springs were localised and the field data discharge, electrical conductivity, $\mathrm{pH}$-value and temperature of each spring were measured. Discharge was measured by filling a graduated vessel within a defined time period. Since all springs except Q1 show discharge values below 1 1/s, a 10-1 bucket was used. Only for spring Q1 in the valley floor was a 40-1 barrel a)

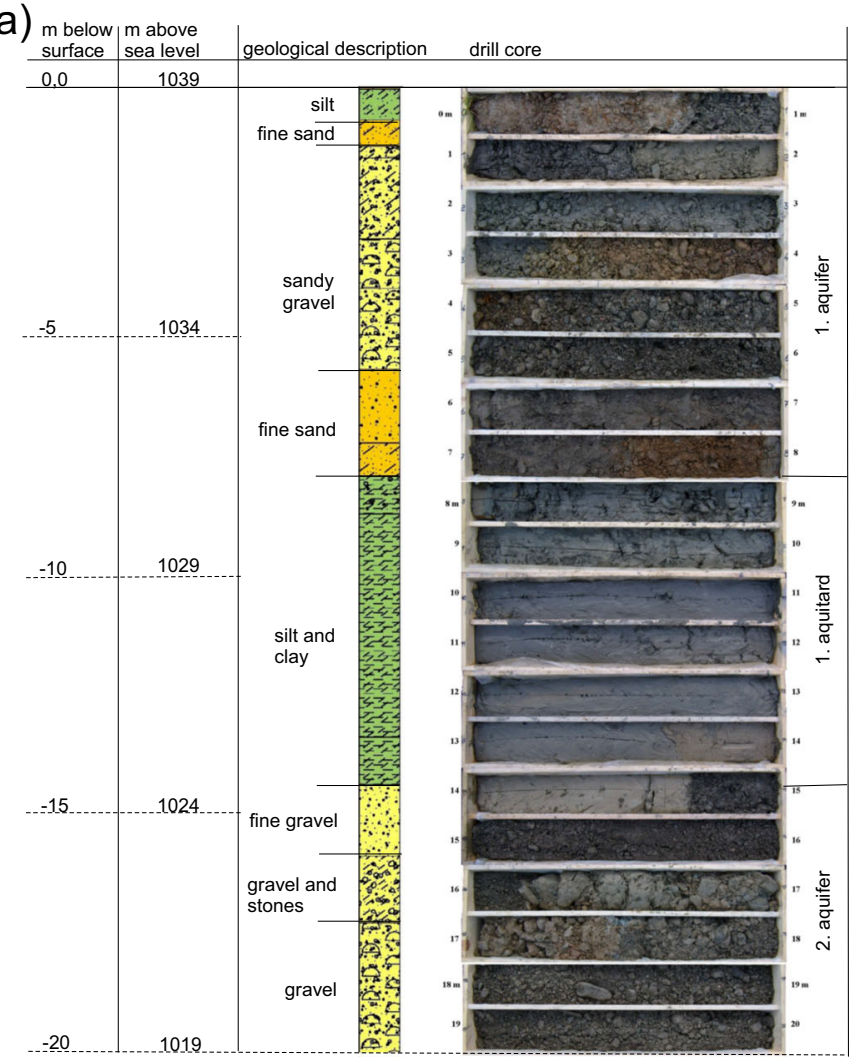

b)

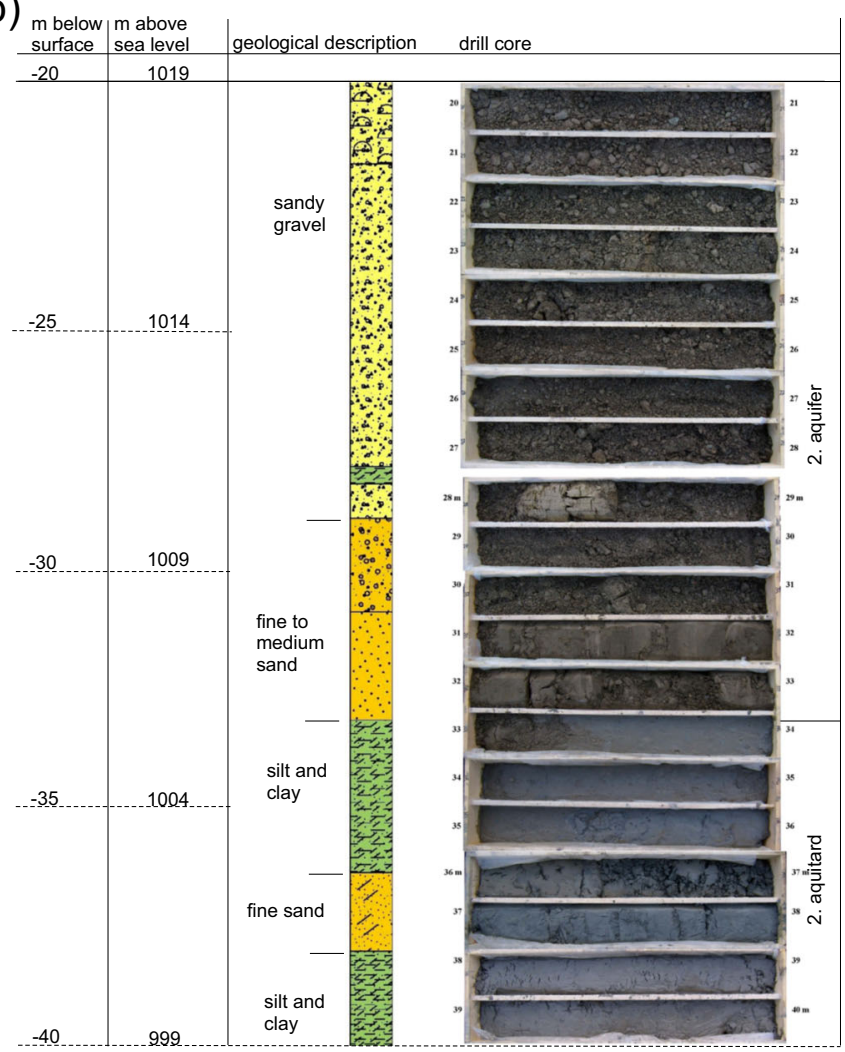

Fig. 2 Drilling core of borehole P1, with first and second aquifer and the intercalated and subjacent clay layers (first and second aquitards). a Depth 0 to $-20 \mathrm{~m}$, b Depth -20 to $-40 \mathrm{~m}$ 
necessary to measure, or rather to estimate, the discharge. Electrical conductivity, $\mathrm{pH}$-value and water temperature were measured by using a WTW 350i multiparameter instrument. The discharge conditions and the geological situation at the discharge locality were documented in a master data sheet for each spring. The field data of the springs were measured twice, for the first time during the mapping activities and a second time during the sampling campaign for hydrochemical analysis some weeks after the first measurement in summer 2011.

\section{Major ion hydrochemistry}

Water samples from eight selected springs and both of the groundwater bodies (sampling points are marked in Fig. 1c) were taken once in summer 2011 after hydrogeological mapping was completed. The selection of analysed springs was guided by the location of the spring issue and the field parameters of the spring water and comprises spring issues on the Höllenberg slope in higher and lower altitudes and springs at the valley floor. Moreover, the mineralisation of the springs was considered by sampling springs with low as well as high electrical conductivity values. The hydrochemcial composition of spring waters can strongly differ due to seasonal influences; thus, time series of hydrochemical data are usually considered for the classification of spring issues (Xanke et al. 2015). However, with regard to the very clear differences between distinct groups of springs in the present study area a single data set of main ion compositions of various springs was considered to be appropriate for a first classification.

The study focused on the major ions calcium $\left(\mathrm{Ca}^{2+}\right)$, magnesium $\left(\mathrm{Mg}^{2+}\right)$, sodium $\left(\mathrm{Na}^{+}\right)$, potassium $\left(\mathrm{K}^{+}\right)$, sulphate $\left(\mathrm{SO}_{4}{ }^{2-}\right)$, chloride $\left(\mathrm{Cl}^{-}\right)$and bicarbonate $\left(\mathrm{HCO}_{3}{ }^{-}\right)$as these parameters are significant for the allocation of water types to various catchments or flow systems. As shown in Kralik et al. (2005), the majority of groundwater from alpine aquifers, also within silicate lithologies are of $\mathrm{Ca}-\mathrm{Mg}-\mathrm{HCO}_{3}$ type. The field parameters electrical conductivity, $\mathrm{pH}$-value and water temperature were measured during the water sampling. Spring waters were sampled directly at the spring issue to avoid falsifications due to degassing, temperature variations or atmospheric oxygen influences. Groundwater was pumped from the wells P1 and P1a with a centrifugal pump. The complete volume of the well was pumped before taking the sample.

Samples were taken in 0.5-1 and 0.2-1 polyethylene bottles from each spring and well. The 0.2-1 samples were acidified with $\mathrm{HNO}_{3}$ to stabilise the dissolved major cations and the 0.5-1 samples were stored in cool boxes. The samples were rapidly conveyed to a certified laboratory in the city of Salzburg (Salzburg-AG Wasserlabor) and analysed with inductively coupled plasma mass spectrometry (ICP-MS), photometer and titration methods.
The water type differentiation was based on the aforementioned major ions. The data were processed by using the software AquaChem 2014.2 by Waterloo Hydrogeologic. The classification and the comparison of the water quality of various springs can provide valuable indications to aid the reconstruction of the flow history of spring waters. This fact can be used to assign springs to different aquifer lithologies (Kilchmann et al. 2004); however, hydrochemistry can also indicate different flow paths within the same lithology representing shallow or deep circulation systems and short or longer mean residence times (Appelo and Postma 2005).

\section{Stable isotope hydrology}

Samples of the two wells, two springs, and surface water from the River Gurk were taken on a monthly basis for stable isotope analyses between April 2008 and March 2009 (isotope sampling points are marked in Fig. 1c. The samples were stored in polyethylene bottles and analysed after the complete sampling period in a certified laboratory in Graz (Joanneum Research). The measurements were conducted by isotope ratio mass spectrometry using Vienna Standard Mean Ocean Water as the reference standard.

The effect of fractionation with altitude of the stable isotope oxygen-18 $\left({ }^{18} \mathrm{O}\right)$ can be used to determine the mean elevation of the infiltration areas of various springs (Moser and Rauert 1980; Clark and Fritz 1997; Mook 2006) - the altitude effect. At higher altitudes with lower mean temperatures, clouds are isotopically depleted due to condensation processes. The higher the elevation of precipitation the lower is the content of ${ }^{18} \mathrm{O}$ in the falling rain; thus, the comparison of the isotope signals of springs and wells in the study area allows a relative determination of mean catchment areas.

Ideally, the isotope composition of spring waters can be referred to the isotope signal of infiltrating precipitation to determine the absolute value of mean elevations. Mean isotope signatures from at least two precipitation sampling points at various elevations are necessary for the correlation between altitude and stable isotope ratios - the altitude gradient. The Austrian Network of Isotopes in Precipitation (ANIP; Kralik et al. 2003) is a very well-designed and dense network and a very useful tool for hydrogeological purposes. However, in the present study area, no ANIP data were available to estimate the decrease of ${ }^{18} \mathrm{O}$ with elevation; thus spring Q35 was used as the calibration point. Due to its low electrical conductivity $(29 \mu \mathrm{S} / \mathrm{cm})$ and the comparably low $\mathrm{pH}$ value of 6.5 , this spring was characterised as the drainage of a very shortterm flow system with a small catchment directly above the discharge area. The spring emerges at an altitude of 1,400 m asl on the western Höllenberg slope (Fig. 1c). According to Clark and Fritz (1997) the altitude gradient for $\delta^{18} \mathrm{O}$ can vary in the range of $0.15-0.5 \%$ per $100 \mathrm{~m}$. Liebminger et al. (2006) showed that the isotope composition of precipitation 
and thus, the precise gradient for each region depends on the topography (e.g. front of orographic barriers, intermountain valleys or large basins) and climatic conditions. Based on selected ANIP datasets of the intermountain station pairs Patscherkofel $(2,245 \mathrm{~m}$ asl $)$ - Innsbruck $(580 \mathrm{~m}$ asl; Liebminger et al. (2006) and Feuerkogel (1,618 m asl) Ebensee (400 m asl; Hilberg and Kreuzer 2013), a lower gradient seems to be valid for intermountain valleys such as the upper Gurk Valley. To evaluate the influence of the altitude gradient on the estimation of mean recharge elevations, a low gradient of $0.15 \%$ and a higher gradient of $0.25 \%$ were used to determine mean catchments of the springs and groundwater in the study area. In combination with these mean altitude gradients, the data from Q35 were used to estimate the catchment elevation of water emerging at springs at the valley floor (Q1, Q2), the water from the first and second groundwater bodies (P1 and P1a) and Gurk surface water.

The isotope composition of precipitation varies with air temperature as result of temperature variations over the hydrological year. Winter precipitation (snow or cold rain) has lower ${ }^{18} \mathrm{O}$ values than warmer summer rain - the temperature effect (Mook 2006). In groundwater with short mean residence times in the range of some months or less, the precipitation input signal is more or less directly transported to the spring. Within flow systems with mean residence times in the range of some years, the seasonal isotope signal is damped. Variations of isotope composition in spring waters are low; thus, the variability of the ${ }^{16} \mathrm{O} /{ }^{18} \mathrm{O}$-ratio over the hydrological year may indicate differences in the mean residence times between various springs (Etcheverry and Vennemann 2009).

\section{Results and discussion}

\section{Geological and hydrogeological setting}

\section{Porous aquifer of the Gurk Valley}

The internal structure of the upper most $40 \mathrm{~m}$ has been investigated using three boreholes situated between the foot of the slope of the Höllenberg and the Gurk riverbank. The position of the boreholes is presented in Fig. 1d. The geological setting is shown in Fig. 2 by the example of borehole P1. The uppermost $8 \mathrm{~m}$ are generally built up of coarse-grained fluviatile sediments, namely gravel and sand. This layer represents the first unconfined aquifer which interacts directly with the surface water of the River Gurk, which is followed by a clay and silt layer of approximately 7-m thickness that can be considered as first aquitard or aquiclude. This clay layer can be interpreted as lacustrine sediment deposited during a temporal lake stadium as result of a downstream-situated rockslide barrier. At a depth of $15 \mathrm{~m}$ below the ground is the transition from the silt and clay layer to another fluviatile sandy gravel layer.
The sandy gravel is saturated with groundwater and represents a confined, even slightly artesian second aquifer of approximately 20-m thickness. Below the second aquifer, fine sand and silt layers act as second aquitard. These fine-grained layers were observed until the final borehole depth of $40 \mathrm{~m}$. The groundwater level of the first aquifer and the potentiometric level of the second aquifer were measured twice in September 2008 and January 2009 in each observation well. The resulting groundwater contour maps are shown in Fig. 3.

In the first aquifer, the groundwater flows in NE-SW direction with a medium groundwater gradient of $0.4 \%$. The groundwater varies around $5 \mathrm{~cm}$ between autumn 2008 and early winter 2009 (Fig. 3a). In the second aquifer, the potentiometric level is slightly higher $(10-50 \mathrm{~cm})$ than the surface with its mean elevation of $1,038.80 \mathrm{~m}$ asl. The flow direction within this slightly artesian aquifer varies between NNE-SSW in autumn 2008 and NE-SW in winter 2009. Significant variations of the potentiometric level were only observed in P2 (9 $\mathrm{cm}$ higher in autumn 2008), whereas P1 and P3 show the same water level in autumn 2008 and winter 2009. The groundwater gradient is relatively high with approximately $0.85 \%$ in both cases. As shown in Fig. 3b the groundwater flow is more or less oriented to the spring issue of Q1. Which can be seen as a first hint for interpreting Q1 as a distinct drainage of the second aquifer (see section 'Conclusions').

\section{Höllenberg fractured aquifer}

The Höllenberg is part of the eastern alpine Gurktal Alps which are mainly built up of Paleozoic quartz phyllites, metasandstones and schist. The Höllenberg study area and its geological and hydrogeological situation are shown in Fig. 1c. In the local study area, only quartz phyllites with a few inclusions of green schist are present. Due to the phyllitic and schistose lithology, the Höllenberg can basically be characterised as a low permeability fractured aquifer or even an aquitard. The permeability of such settings is mainly restricted to the disaggregated zones. Aside the upper most weathered zones (Lachassagne et al. 2011), disaggregation zones as result of deglaciation (Reitner et al. 1993) and tectonically fractured zones (Welch and Allen 2014) provide a matrix- and fracture permeability within the hard rocks of the Höllenberg Massif. Bulked zones of intensive weathering are observed in many phyllite outcrops along the Höllenberg slopes. The thickness of the weathered or fractured zones is not known and is assumed to be very variable in the study area. Some phyllite outcrops that are nearly unweathered and less fractured were also observed. Major parts of the hillslopes are covered by detritus and material of fossil rockslides of various grain size (gravel up to rocks). Some small areas are covered by relicts of moraine deposits with the typically widespread grain-size distribution and a high portion of finegrained material. Moraine material and the nearly 
Fig. 3 Groundwater contour maps showing water level on 22 September 2008 and 19 January 2009 for a the first and $\mathbf{b}$ the second aquifer
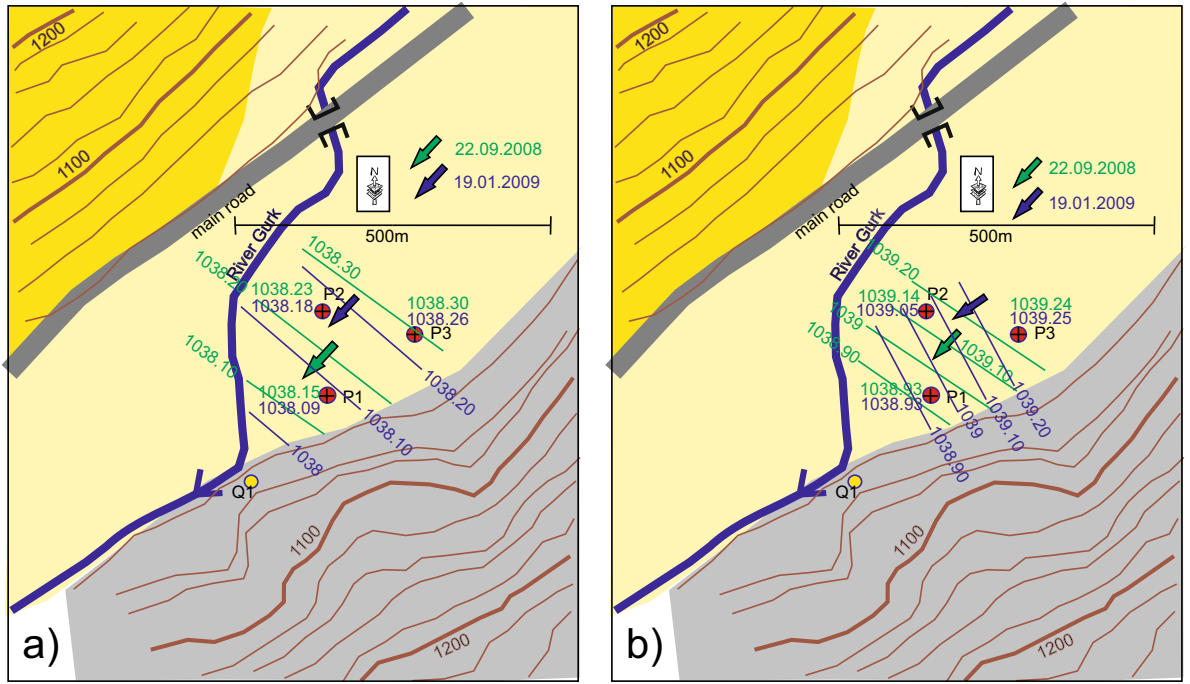

unweathered and less fractured hard rocks can be seen as nonpermeable very local aquicludes within the weathered or fractured hard rock aquifer.

The discharge was measured once during the mapping campaign for each of the 28 detected springs. Eight springs that were selected for hydrochemical investigations were measured again during the sampling. Most of the springs emerging at higher altitudes along the slopes show mean discharge values in the range of less than $1 \mathrm{l} / \mathrm{s}$ and electrical conductivities below $100 \mu \mathrm{S} / \mathrm{cm}$. Their spatial distribution is irregular and in most cases in correlation with outcrops of the aforementioned aquicludes. A second group of springs emerge in the deeper parts of the Höllenberg slopes and show mean electrical conductivities between 100 and $200 \mu \mathrm{S} / \mathrm{cm}$ and also discharge below $1 \mathrm{l} / \mathrm{s}$. Only one significantly bigger spring (Q1 in Fig. 1c,d) emerges at the eastern edge of the valley floor only slightly above the water level of the River Gurk. Discharge values between 20 and $40 \mathrm{l} / \mathrm{s}$ were estimated for this spring. Due to the fact that the spring emerges directly into the River Gurk, only slightly above the water level, it was not possible to measure the exact discharge of this spring.

\section{Major ion composition}

The physio-chemical data are presented in Table 1. The hydrochemical investigations considered 8 springs and two groundwater wells (marked in Fig. 1c). The total mineralisation is documented with regard to the elevation of discharge in Fig. 4. The figure shows a correlation between the elevation and mineralisation of the springs. A group of springs emerging at high altitudes of the Höllenberg Massif shows values below $100 \mu \mathrm{S} / \mathrm{cm}$, a second group of springs situated between 1,040 and 1,400 $\mathrm{m}$ asl and the first aquifer (P1a) shows values in the range of $160-170 \mu \mathrm{S} / \mathrm{cm}$ and the third group consisting of Q1, Q2 and P1-representing the springs in the valley floor and the second aquifer shows values in the range of $250 \mu \mathrm{S} / \mathrm{cm}$.

The Piper plot in Fig. 5 gives an overview of the water composition and shows significant variations mainly in the cation composition, while the anion composition of all the springs, except the obviously superficial Q35 (29 $\mu \mathrm{S} / \mathrm{cm})$, are $\mathrm{HCO}_{3}$-dominated. The total concentrations of the main ions are shown in the Schoeller plot in Fig. 6a, which shows the clear dominance of $\mathrm{HCO}_{3}, \mathrm{Ca}$ and $\mathrm{Mg}$ in all samples and the significantly higher total mineralisation of P1, P1a, Q1 and Q2. The different springs and groundwater vary mostly in their $\mathrm{Ca}-\mathrm{Mg}$ correlation, which is shown in the piper diagram and also in Fig. 6b. While the low mineralised springs show a nearly 1:1 ratio between $\mathrm{Ca}$ and $\mathrm{Mg}$, the springs Q1, Q2, and the groundwater within the second aquifer show a ratio in the range of 2:1, which is a sign for the influence of marbles instead of pure silicate lithology in the Höllenberg catchment. As known from the geological map of the upper Gurk region (Braunstingl et al. 2005) marbles are present in the north of the study area. As shown in Fig. 6c, $\mathrm{SO}_{4}$ concentrations are directly related to $\mathrm{Ca}$ concentrations and thus can be interpreted as a sign for gypsum within the aquifer. Significant $\mathrm{SO}_{4}$ concentrations were only observed in P1a, Q1 and Q2. Slightly higher contents (compared to all other springs) of sodium and chloride as potential indicators for influences of road de-icing can be observed in Q1 and both groundwater wells as shown in Fig. 6d. Both porous aquifers and Q1 may be influences by the main road that crosses the study area and the complete orographical catchment of the River Gurk.

The electrical conductivity is mainly controlled by the $\mathrm{HCO}_{3}$ content (Fig. 6e), while the other anions do not play a significant role in the total mineralisation of the waters (Fig. 6f-h). The content of nitrate (Fig. 6h) as a clear indicator for anthropogenic agricultural influences is very low in all investigated sampling points. 
Table 1 Major ion composition of the investigated springs and wells based on a single measurement campaign in summer 2011

\begin{tabular}{|c|c|c|c|c|c|c|c|c|c|c|c|c|c|c|c|}
\hline Station & $\begin{array}{l}\text { Ground surface } \\
\text { elevation } \\
\mathrm{m} \text { (asl) }\end{array}$ & $\begin{array}{l}\text { Discharge } \\
\text { 1/s }\end{array}$ & $\begin{array}{l}\text { Elevation of } \\
\text { filter screens } \\
\mathrm{m} \text { (asl) }\end{array}$ & $\begin{array}{l}\text { Water level } \\
\text { m (asl) }\end{array}$ & $\begin{array}{l}\text { Temp. } \\
{ }^{\circ} \mathrm{C}\end{array}$ & $\begin{array}{l}\text { Electrical } \\
\text { Cond. } \\
\text { uS/cm }\end{array}$ & $\mathrm{pH}$ & $\begin{array}{l}\mathrm{K} \\
\mathrm{mg} / \\
1\end{array}$ & $\begin{array}{l}\mathrm{Na} \\
\mathrm{mg} / \\
1\end{array}$ & $\begin{array}{l}\mathrm{Ca} \\
\mathrm{mg} / \mathrm{l}\end{array}$ & $\begin{array}{l}\mathrm{Mg} \\
\mathrm{mg} / \\
1\end{array}$ & $\begin{array}{l}\mathrm{Cl} \\
\mathrm{mg} / \\
1\end{array}$ & $\begin{array}{l}\mathrm{SO}_{4} \\
\mathrm{mg} / \\
1\end{array}$ & $\begin{array}{l}\mathrm{HCO}_{3} \\
\mathrm{mg} / \mathrm{l}\end{array}$ & $\begin{array}{l}\mathrm{NO}_{3} \\
\mathrm{mg} / \mathrm{l}\end{array}$ \\
\hline Q1 & 1,039 & $\sim 40$ & - & - & 7.8 & 221 & 8 & 0.7 & 3.2 & 33.1 & 10.2 & 4.9 & 17.7 & 125 & 3. \\
\hline Q2 & 1,100 & 0.7 & - & - & 6.6 & 215 & 7.9 & 0.5 & 1.5 & 33.2 & 10.6 & 0.7 & 14.3 & 137 & 5.1 \\
\hline Q11 & 1,600 & 0.05 & - & - & 7.6 & 48 & 7.4 & 0.3 & 1.9 & 3.81 & 2.3 & 0.7 & 3.1 & 22.6 & n.m. \\
\hline Q15 & 1,600 & 0.1 & - & - & 6.8 & 65 & 7.8 & 0.3 & 1.4 & 6.56 & 3.4 & 0.6 & 1.8 & 37.8 & 2.1 \\
\hline Q23 & 1,400 & 0.25 & - & - & 7.4 & 166 & 7.6 & 0.3 & 2.7 & 17.5 & 12.1 & 0.9 & 8.1 & 107 & 1.5 \\
\hline Q26 & 1,100 & 0.15 & - & - & 7.1 & 162 & 7.8 & 0.4 & 1.3 & 28 & 5.9 & 0.8 & 8.1 & 104 & 3.7 \\
\hline Q34 & 1,650 & 0.02 & - & - & 6.5 & 37 & 7.4 & 0.3 & 1.2 & 1.65 & 1.6 & 0.4 & 1.0 & 14 & 1.1 \\
\hline Q35 & 1,400 & 0.3 & - & - & 6.3 & 29 & 6.6 & 0.5 & 1.0 & 1.44 & 0.8 & 0.6 & 3.6 & 4.9 & 2.0 \\
\hline $\mathrm{P} 1$ & $1,038.7$ & - & $1,024-1,007$ & $1,039.10$ & 6.3 & 256 & 7.5 & 0.7 & 3.4 & 34.06 & 10.2 & 5.4 & 17.4 & 128.4 & 3.0 \\
\hline P1A & $1,038.7$ & - & $1,037-1,032$ & $1,038.10$ & 7.8 & 162 & 7 & 0.7 & 23.0 & 19.46 & 5.8 & 3.9 & 5.6 & 82.3 & 2.0 \\
\hline
\end{tabular}

In summary, the hydrochemical composition of the springs and wells, although only based on one sampling campaign, shows a clear classification into three distinct groups of waters: (1) superficial waters with a low total mineralisation emerging in high altitudes, groundwater circulation is restricted to the soil zone and the slope detritus; (2) medium mineralised springs at various altitudes, connected to a shallow flow system within the weathered parts of the hard rock aquifer of the Höllenberg and in the upper porous aquifer in the valley floor; and (3) a group of comparably high mineralised waters, emerging at the valley floor and circulating in the lower porous aquifer, respectively.

\section{Stable isotopes}

The results from the monthly measurements of ${ }^{18} \mathrm{O}$ values are presented in Fig. 7. The time series of $\delta^{18} \mathrm{O}$ from one superficial spring (Q35), from the Gurk surface water, from the springs emerging at the valley floor (Q1 and Q2), and the first and second porous aquifers (P1a, P1) indicate different kinds of groundwater flow systems. Group 1 represents relatively

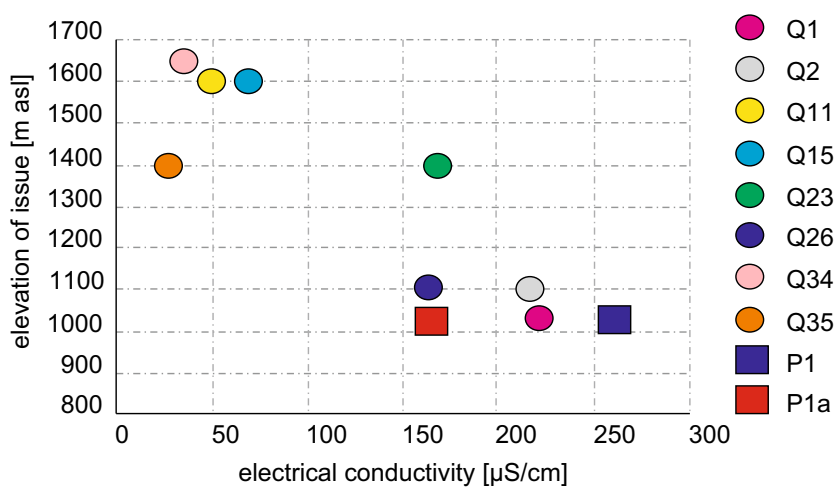

Fig. 4 Cross plot of spring elevation versus electrical conductivity. The diagram shows a clear correlation between altitude of discharge and total mineralisation enriched water (higher $\delta^{18} \mathrm{O}$ values) and includes the springs Q2, and Q35. Group 2 is characterised by relatively depleted $\delta^{18} \mathrm{O}$ values and is represented by $\mathrm{Q} 1, \mathrm{P} 1$, and the Gurk surface runoff. The strongly depleted waters from the River Gurk in April and May 2008 are typical for snowmelt runoff in springtime. The shallow groundwater in the first aquifer pumped from the well Pla shows strong variations with similarities to group 1.

The variations of $\delta^{18} \mathrm{O}$ values in the observed period deliver some qualitative information about the mean residence times, and thus the flow dynamics in the corresponding aquifer and the influence of surface water. The stable isotope composition of precipitation shows a strong annual variation due to different fractionation processes under cold or warm conditions. Generally, warm summer rain shows a relatively higher content of ${ }^{18} \mathrm{O}$ than cold winter rain which is relatively depleted in ${ }^{18} \mathrm{O}$. In an aquifer with short mean residence times, these annual variations can be observed also in the springs. In a groundwater body with a high retention capacity and longer mean residence times, the variation of the precipitation input is damped due to mixing processes within the aquifer. Springs emerging from such aquifers do not show significant annual variations of their isotope signature. In Fig. 7, the measurement uncertainties in the range of $\pm 0.1 \%$ are marked for each data. Significant variations can be observed for the springs of group 1, well P1a and Gurk surface water. In contrast, spring Q1 and groundwater removed from well P1 (second porous aquifer) show very stable isotope data over the entire observation period. Their variations are within the measurement error. The stable isotope hydrographs of spring Q1 and well P1 indicate a mean residence time of at least more than 1 year (Clark and Fritz 1997), and thus an appropriate retention capacity in the aquifer.

As explained in section 'Stable isotope hydrology' and shown in Fig. 8a,b, a range of possible altitude gradients of $\delta^{18} \mathrm{O}$ decrease between $0.15 \%$ per $100 \mathrm{~m}$ and $0.25 \%$ per $100 \mathrm{~m}$, respectively based on the mean $\delta^{18} \mathrm{O}$ value of spring 
Fig. 5 Piper diagram displaying the water samples from the Höllenberg Massif and the Gurk Valley porous groundwater aquifers. All samples, except Q35, are dominated by bicarbonate, calcium, and magnesium
Q35 leads to estimated mean elevations of catchments between 1,600 $\mathrm{m}$ asl (lower value for higher gradient and 1, $950 \mathrm{~m}$ asl (upper value for lower gradient) for spring Q1, the second aquifer and for Gurk surface waters. The first porous aquifer shows a mean elevation of its catchment in the range of 1,450 or 1,500 $\mathrm{m}$ asl, respectively and spring Q2, emerging at the valley floor, shows a mean altitude of $1,300 \mathrm{~m}$ asl.

Since the Höllenberg summit lies at an altitude of 1,772 m asl, it can be identified as the potential catchment area of the springs Q35, Q2 and the first porous aquifer (P1a). Based on the results of the stable isotope measurements, the Höllenberg Massif cannot be the catchment for the groundwater emerging in spring Q1, the water within the second porous aquifer and the Gurk surface water.

\section{Conceptual hydrogeological model}

Based on the field observations in combination with hydrochemical and isotope data a conceptual model for the various flow systems in the upper Gurk Valley has been developed and is shown in Figs. 9 and 10 as the final result of the presented study.Three different flow systems are represented in the observed groundwater regimes and were detected in the study area:

- Very shallow and local flow systems in the upper-most unconsolidated cover of the Höllenberg hillslope. These small systems are represented by small irregularly distributed springs with low mineralisation and catchments very close to the spring issues. Groundwater flow is gravity driven within the detrital

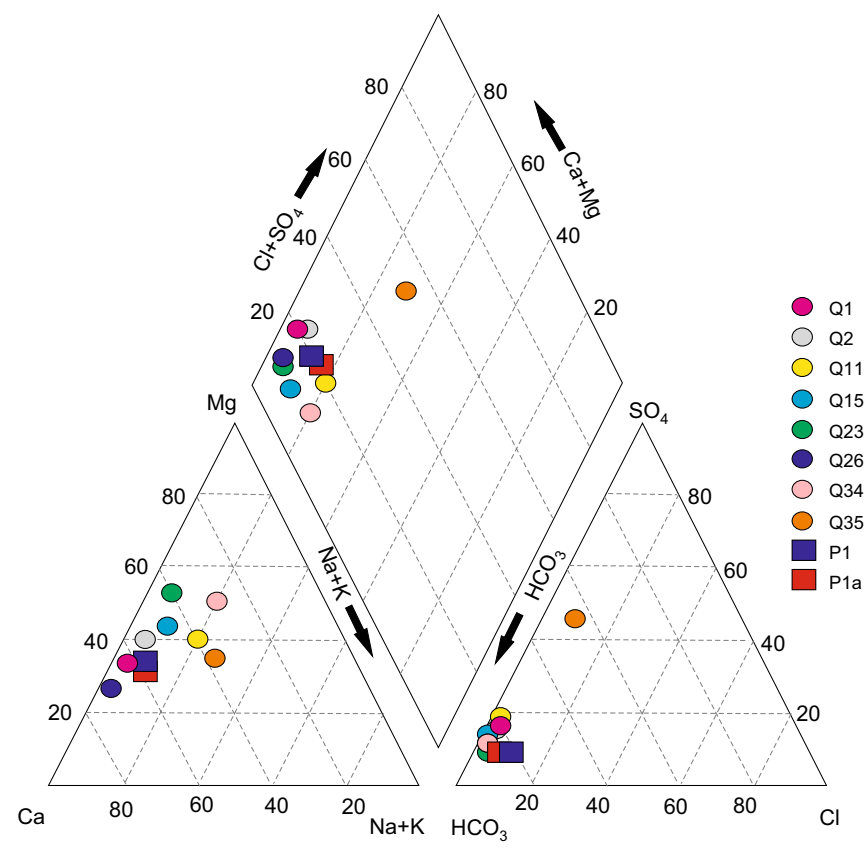

cover of the hillslope. Moraine material and unweathered hard rocks act as a local aquitard and force the groundwater to emerge. Based on the spatial distribution, the hydrochemical as well as the isotope data this flow system 1 (presented in Fig. 9a) is represented by the springs Q11, Q15, Q34, and Q35.

- An intermediate flow system (flow system 2 in Fig. 9a) that is restricted to the weathered and fractured upper parts of the phyllitic hard rocks of the Höllenberg Massif. Basically, the phyllitic lithology stands for very low permeability and thus very little subsurface flow. However, a network of fractures bulked by weathering processes enables rainfall to percolate into the hard rock aquifer. Weathering and thus permeability decrease with depth. The unweathered phyllite can be characterised as an aquitard. Springs emerge along boundaries between weathered and fresh rock layers or infiltrate directly into the first porous aquifer in the Gurk Valley. The sampling points that are assigned to this flow system are Q2, Q23, Q26 and the first porous aquifer itself, represented by the observation well P1a.

- Finally, a regional flow system with a recharge area with a mean elevation that is significantly higher than the Höllenberg summit must be the origin of the groundwaters circulating in the second porous aquifer, represented by well P1 and the large spring Q1 at the valley floor. Since the isotope signature of the Gurk surface waters is very similar to those of P1 and Q1 (except during snowmelt periods), it can be assumed that the catchment of P1 and Q1 is comparable to the Gurk catchment and comprises the mountain region of the Gurktal Alps marked as the 

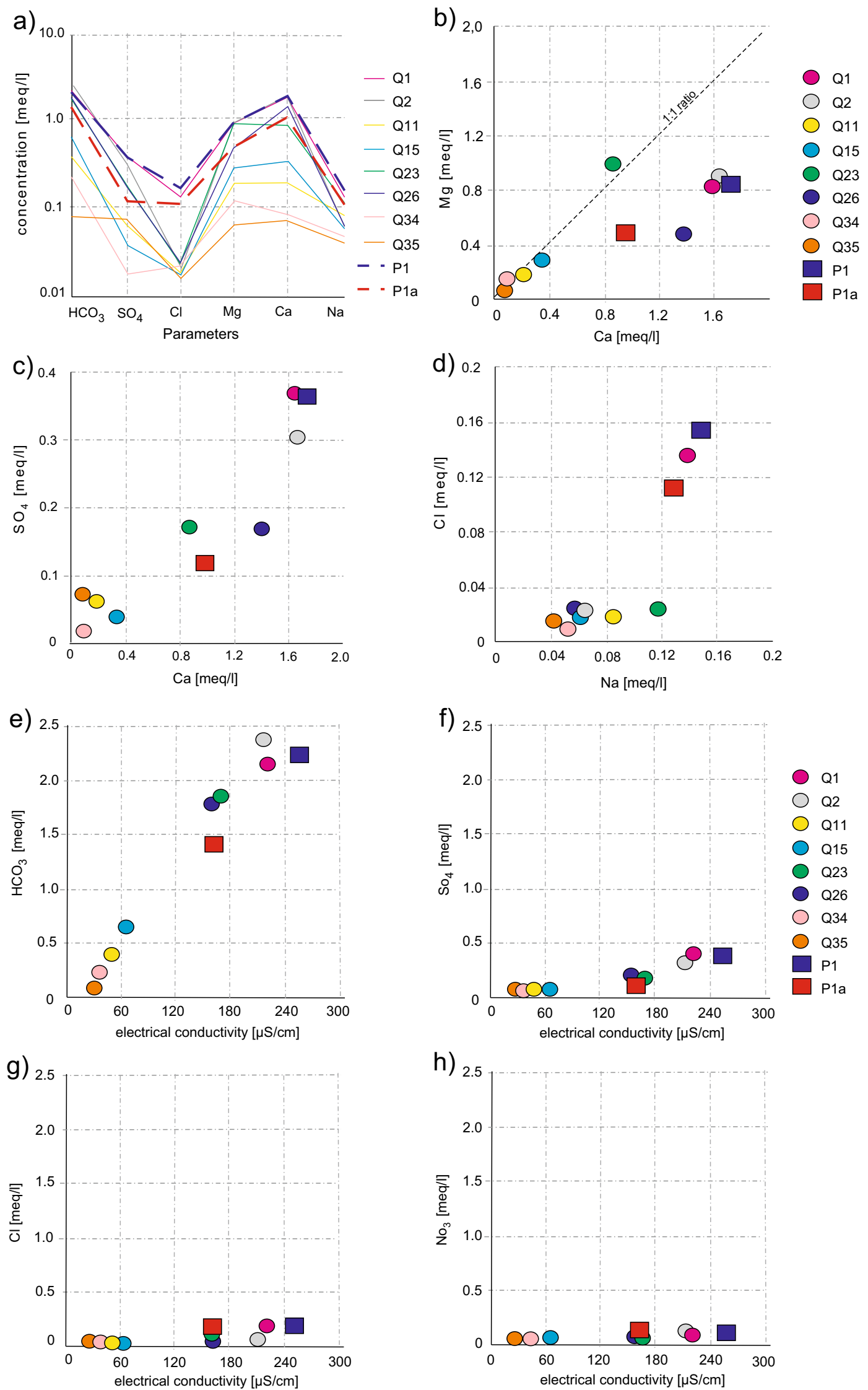
Fig. 6 a Schoeller plot showing the concentrations of the main parameters for each sampling point. b-d Cross plots of $\mathbf{b}$ the $\mathrm{Ca}-\mathrm{Mg}$ ratio, showing the influence of marble for $P 1, Q 1$ and $Q 2$, c the $\mathrm{Ca}-$ $\mathrm{SO}_{4}$ ratio as indicator of gypsum in the aquifer, $\mathbf{d}$ the $\mathrm{Na}-\mathrm{Cl}$ ratio (chloride concentrations in $P 1, P 1 a$ and $Q 1$ are related to sodium as evidence for street de-icing). $\mathbf{e}-\mathbf{h}$ cross plots of electrical conductivity versus anion concentrations: $\mathbf{e} \mathrm{HCO}_{3}, \mathbf{f} \mathrm{SO}_{4}, \mathbf{g ~ C l}$, h very low $\mathrm{NO}_{3}$ concentrations show that the samples are free of further anthropogene influences. The diagrams show the clear dominance of $\mathrm{Ca}, \mathrm{Mg}$ and $\mathrm{HCO}_{3}$ in all samples. These ions are mainly responsible for the total mineralisation

orographical catchment of flow system 3 in Fig. 10. The very stable isotope development in P1 and Q1 over the observation period of 1 year proves that there is no direct infiltration of Gurk surface water into the second aquifer upstream of the study area since the signals of snowmelt are not present in these measuring points. The very similar hydrochemcial composition and isotope signature of P1 and Q1 as well as the comparable potentiometric surface indicates that Q1 is a natural artesian discharge of the second porous aquifer and has no direct connection to the Höllenberg Massif fractured aquifer and also not to the first porous groundwater body. The distinct discharge of the second aquifer at Q1 must be the result of a very special geological situation at the Höllenberg hill foot with interlocked alluvial, lacustrine and hill slide sediments as is schematically shown in Fig. 9b.

\section{Conclusions}

The presented case study is an example of the typical complex hydrogeological situation within a glacially overdeepend and postglacially filled small alpine valley.
It also shows, how a deeper insight and the understanding of this complexity enables spatial restrictions and user conflicts between drinking-water protection and the requirements of the existing land use to be overcome. Usually, the direct use of groundwater pumped from the porous aquifer in the valley floor is difficult since existing land uses in the often densely populated valleys hinder a sufficient protection of the catchments. The use of springs at the hillslopes fails because of the difficulties to access these springs and to build pipelines in the steep terrain.

By means of a comparatively simple investigation based on hydrogeological mapping, drilling in the unconsolidated sediments, very limited hydrochemical information and a time series of ${ }^{18} \mathrm{O}$ values from selected sampling points, it was possible to support the water suppliers with hydrogeological information that enables them to implement a well-protected sustainable drinking-water plant in the second aquifer.

The sedimentary sequence with intercalated coarsegrained alluvial and fine-grained lacustrine sediments is a typical structure of a small alpine valley, resulting from recurring postglacial rockslide events, which created temporal barriers for the surface runoff in the narrow valley. Silt and clay layers were deposited in the resulting temporal lake and after the erosion of the rockslide barrier, alluvial coarse-grained sedimentation covered the silt and clay layers. Repeating processes of alluvial sedimentation, landslides and lake developments lead to multiple alternating sequences of high permeable aquifers and low or even non-permeable aquitards or aquicludes. In the present study, the uppermost two lake phases with intercalated alluvial layers are presented in borehole P1.

The second typical hydrogeological property of small alpine valleys is the direct interaction between the porous aquifers in the valley floor and the nearby fractured hard rock
Fig. 7 Time series of $\delta^{18} \mathrm{O}$ development for the time period between April 2008 and March 2009. The diagram shows that one group of waters shows very stable values over the observation period on a low level, while the other group shows higher $\delta^{18} \mathrm{O}$ values but also stronger variabilities. $\delta^{18} \mathrm{O}$ values below $-11 \%$ in the River Gurk in April and May can be interpreted as snowmelt influence

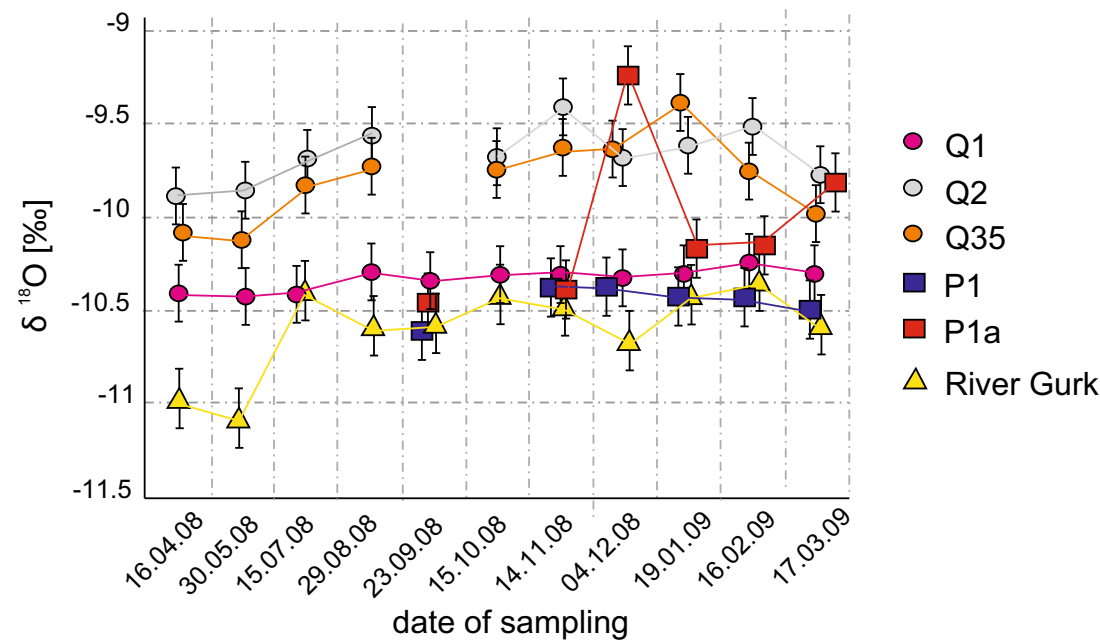




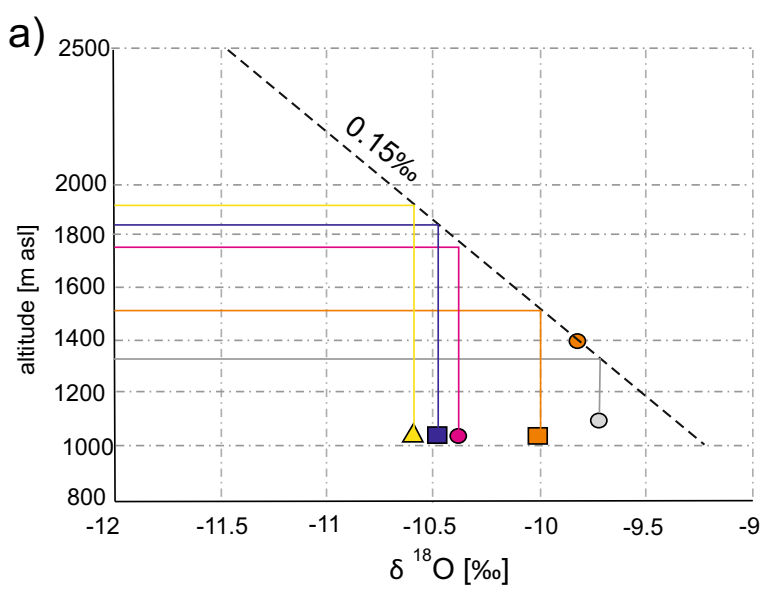

Fig. 8 Determination of catchment elevations by means of the weighted mean $\delta^{18} \mathrm{O}$ values. Under the assumption of a low $(0.15 \%)$ or medium $(0.25 \%$ ) altitude gradient, the resulting mean catchment elevations for

aquifers. The hard rock aquifers are usually drained by distinct springs or by diffuse flow into the porous aquifers or the surface runoff.

b)

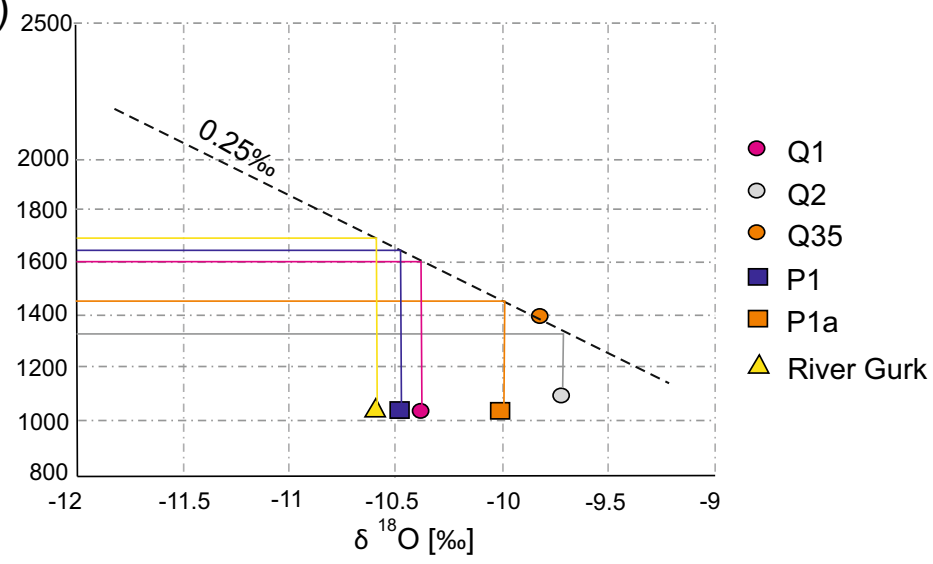

Q1, P1 and the River Gurk surface waters are too high for a nearby catchment at the Höllenberg Massif

In the presented study, it was possible to identify three partly interacting flow systems within porous and fractured aquifers and different catchments. The general concept of flow

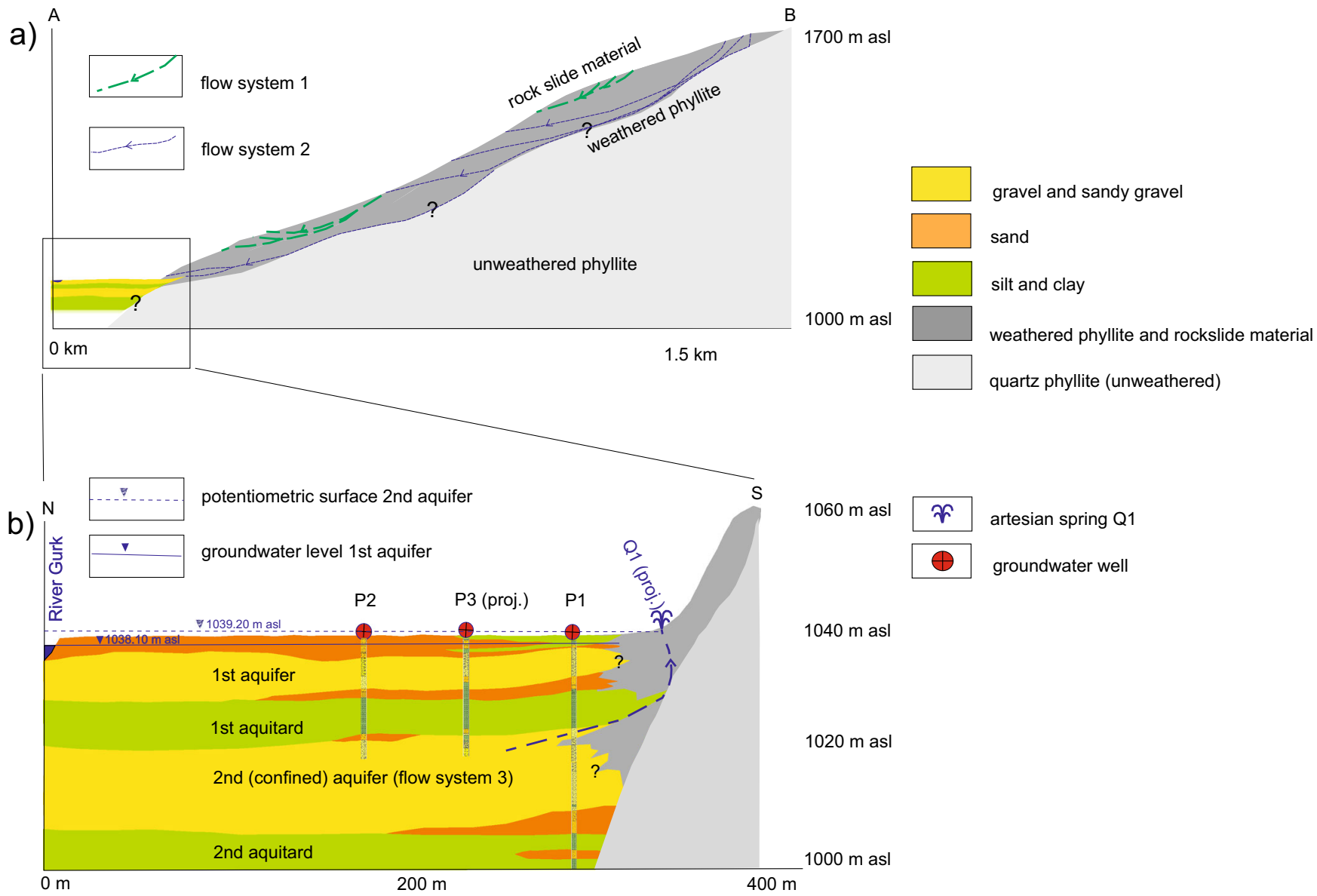

Fig. 9 Conceptual hydrogeological model of the upper Gurk Valley; three flow systems, differing in scale and characteristics, are involved in the hydrogeological setting of the comparably small alpine valley (position of the cross section pictured in Fig. 10): a flow systems 1 and 2 are related to the Höllenberg slopes in different stages of weathered or fractured zones. b upper $40 \mathrm{~m}$ of the unconsolidated valley fill provide two aquifers divided by the first aquitard and underlain by the second aquitard. Spring $Q 1$ is directly connected to the second confined aquifer (5 times exaggerated cross section, location pictured in Fig. 1d) 


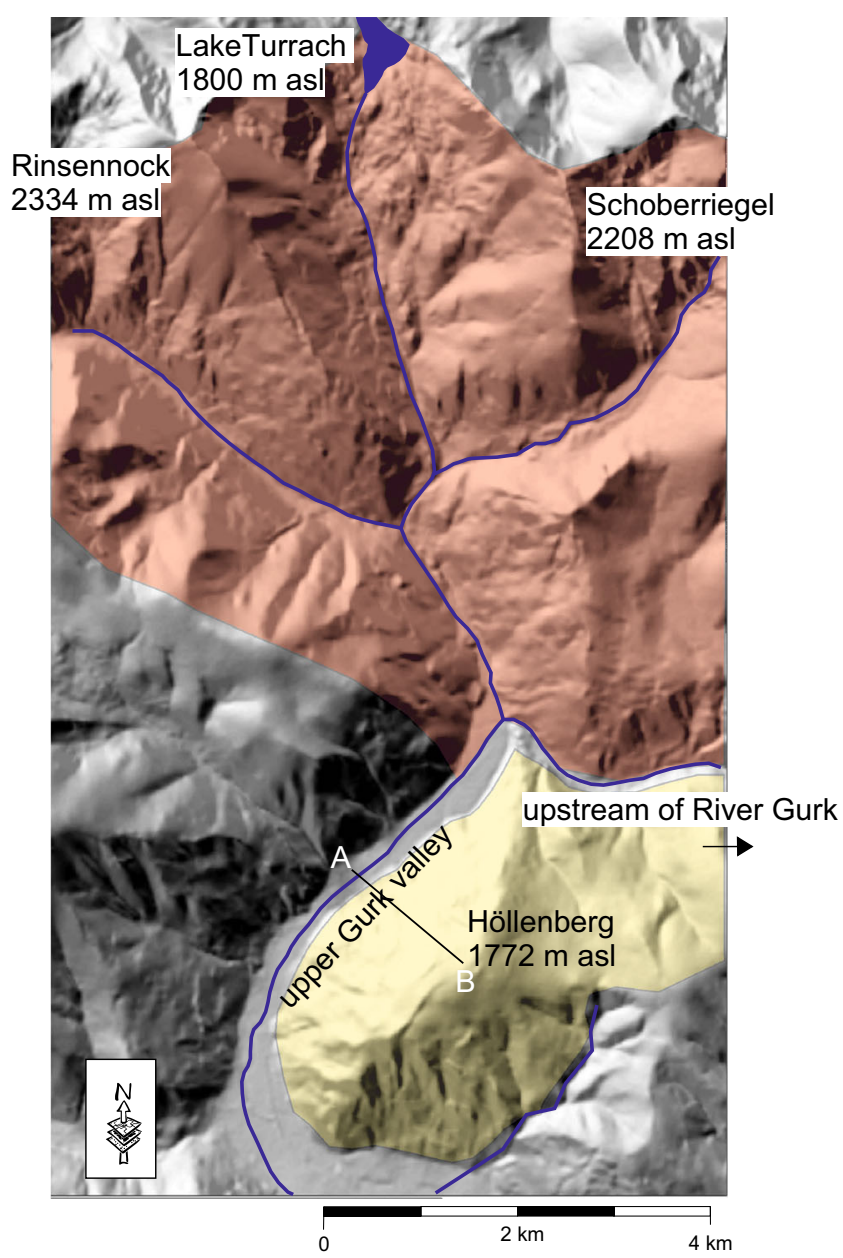

Fig. 10 Potential catchments of flow systems 1 and 2 (yellow), and flow system 3 (red)

systems introduced by Toth (1999), in combination with the conceptual model of flow in mountainous fractured hard rocks described for instance by Welch and Allen (2014), was the basis for the interpretation of the measured data.

Based on the findings of the study, a pumping well that provides a sufficient amount of potable water from a wellprotected groundwater body was installed at site P1. Although a detailed determination of the catchment is not possible based on the available data, the high mean elevation of the catchment is clearly indicated by the ${ }^{18} \mathrm{O}$ values and also supported by the hydrochemical signature.

It can be assumed that the catchment area of the second porous aquifer lies in a high mountain region far away from the current land users and the potential groundwater threats. In addition, the obviously long mean residence times, indicated by the stable ${ }^{18} \mathrm{O}$ values of waters abstracted from $\mathrm{P} 1$ and $\mathrm{Q} 1$ over the observation period ensures good water quality. Artesian conditions and the existence of the 7-m-thick clay layer of low permeability prevents the infiltration of surface water or groundwater from the flow systems 1 and 2. Based on the results of the study, it was possible to resign the delineation of a protection zone in the intensively used region. The results can be transferred to other geologically comparable settings and help to overcome some of the typical problems that water suppliers in alpine valleys are confronted with.

Acknowledgements Open access funding provided by Paris Lodron University of Salzburg. The authors are grateful to the community of Ebene Reichenau in Carinthia for the supply and approval for data publication. Thanks to Jochen Schlamberger (Carinthian Geological Survey) for inspiring discussions and helpful recommendations and to Daniel Dirnberger for his mapping and sampling activities. We greatly acknowledge the constructive suggestions by three anonymous reviewers and the associate editor of Hydrogeology Journal.

Open Access This article is distributed under the terms of the Creative Commons Attribution 4.0 International License (http:// creativecommons.org/licenses/by/4.0/), which permits unrestricted use, distribution, and reproduction in any medium, provided you give appropriate credit to the original author(s) and the source, provide a link to the Creative Commons license, and indicate if changes were made.

\section{References}

Appelo CAJ, Postma D (2005) Geochemistry, groundwater and pollution, 2nd edn. Balkema, Leiden, The Netherlands

Bleibinhaus F, Hilberg S (2012) Shape and structure of the Salzach Valley, Austria, from seismic travel time tomography and full waveform inversion. Geophys J Int 189(3):1701-1716. doi:10.1111/j. 1365-246X.2012.05447.x

Boutt DF, Diggins P, Mabee S (2010) A field study (Massachusetts, USA) of the factors controlling the depth of groundwater flow in crystalline fractured rock terrain. Hydrogeol J 18:1839-1854. doi:10.1007/ s10040-010-0640-y

Braunstingl R (C), Pestal G, Hejl E, Egger H, van Husen D, Linner M, Mandl G, Moser M, Reitner J, Rupp C, Schuster R (2005) Geologische Karte von Salzburg 1: 200.000 mit Erläuterungen [Geological map of Salzburg 1:200.000 with commentary]. Geologische Bundesanstalt, Vienna

Carinthian Governmental Administration (2015) KAGIS http://gis.ktn. gv.at/atlas. Accessed 28 December 2015

Clark I, Fritz P (1997) Environmental isotopes in hydrogeology. Lewis, New York

Etcheverry D, Vennemann T (2009) Isotope im Grundwasser: Methoden zur Anwendung in der hydrogeologischen Praxis [Isotopes in groundwater: methods for the hydrogeological application]. Umweltwissen Bd. 0930. Bundesamt für Umwelt, Bern, Switzerland

Gabrielli CP, McDonell JJ, Jarvis WT (2012) The role of bedrock groundwater in rainfall-runoff response at hillslope and catchment scales. J Hydrol 450-451:117-133

Hilberg S, Kreuzer M (2013) Identification of a deep flow system in a dolomitic alpine aquifer: case study Wimmerbauern spring, Bad Ischl. Aust J Earth Sci 106(1):16-25

Hilberg S, Brandstätter J, Glück D (2013) $\mathrm{CO}_{2}$ partial pressure and calcite saturation in springs: useful data for identifying infiltration areas in mountainous environments. Environ Sci: Processes Impacts 15: 823-832. doi:10.1039/c3em30973h

Kilchmann S, Waber HN, Parriaux A, Bensimon M (2004) Natural tracers in recent groundwaters from different Alpine aquifers. Hydrogeol J 12:643-661. doi:10.1007/s10040-004-0366-9

Kosugi K, Fujimoto M, Katsura S, Kato H, Sando Y, Mizuyama T (2011) Localised bedrock aquifer distribution explains discharge from 
headwater catchment. Water Resour Res 47. doi: 10.1029/ 2010WR009884

Kralik M, Papesch W, Stichler W (2003) Austrian network of isotopes in precipitation (ANIP): quality assurance and climatological phenomenon in one of the oldest and densest networks in the world. Isot Hydrol Integr Water Resour Manag 23:146-149

Kralik M, Zierzitz I, Grath J, Vincze G, Philippitsch R, Pavlik H (2005) Hydrochemische Karte Österreichs [Hydrochemical map of Austria]. Report 269, Umweltbundesamt, Vienna

Lachassagne P, Wyns R, Dewandel B (2011) The fracture permeability of hard rock aquifers is due neither to tectonics nor to unloading, but to weathering processes. Terra Nov. 23:145-161. doi:10.1111/j.13653121.2011.00998.x

Liebminger A, Haberhauer G, Papesch W, Heiss G (2006) Correlation of the isotopic composition in precipitation with local conditions in alpine regions. J Geophys Res 111, D05104. doi:10.1029/ 2005JD006258,2006

Mook WG (2006) Introduction to isotope hydrology: stable and radioactive isotopes of hydrogen, oxygen and carbon. Taylor and Francis, London

Moser H, Rauert W (1980) Isotopenmethoden in der Hydrogeologie (Isotope methods in hydrogeology) Reihe Lehrbuch der Hydrogeologie 8, Bornträger, Berlin

Preusser F, Reitner J, Schlüchter C (2010) Distribution, geometry, age and origin of overdeepened valleys and basins in the Alps and their foreland. Swiss J Geosci 103:407-426. doi:10.1007/s00015-0100044-y

Rantitsch G (2001) The fractal properties of geochemical landscapes as an indicator of weathering and transport processes within the Eastern Alps. J Geochem Explor 73:27-42
Reitner J, Lang M, van Husen D (1993) Deformation of high slopes in different rocks after Würmian deglaciation in the Gailtal (Austria). Quat Int 18:43-51

Salcher BC, Meurers B, Smit J, Decker K, Holzel M, Wagreich M (2012) Strike-slip tectonics and quaternary basin formation along the Vienna basin fault system inferred from Bouguer gravity derivatives. Tectonics 31(3). doi: 10.1029/2011TC002979

Salve R, Rempe DM, Dietrich WE (2012) Rain, rock moisture dynamics, and the rapid response of perched groundwater in weathered, fractured argillite underlying a steep hillslope. Water Resour Res 48, W11528. doi:10.1029/2012WR012583

Toth J (1999) Groundwater as a geological agent: an overview of the causes, processes and manifestations. J Hydrol 7:1-14

Viviroli D, Dürr HH, Messerli B, Meybeck M, Weingartner R (2007) Mountains of the world, water towers for humanity: typology, mapping, and global significance. Water Resour Res 43, W07447. doi: 10.1029/2006WR005653

Welch LA, Allen DM (2012) Consistency of groundwater flow patterns in mountainous topography; implications for valley bottom water replenishment and for defining groundwater flow boundaries. Water Resour Res 48, W05526. doi:10.1029/2011WR010901

Welch LA, Allen DM (2014) Hydraulic conductivity characteristics in mountains and implications for conceptualising bedrock groundwater flow. Hydrogeol J 22:1003-1026. doi:10.1007/s10040-014$1121-5$

Xanke J, Goeppert N, Sawarieh A, Liesch T, Kinger J, Ali W, Hötzl H, Hadidi K, Goldscheider N (2015) Impact of managed aquifer recharge on the chemical and isotopic composition of a karst aquifer, Wala reservoir, Jordan. Hydrogeol J 23:1027-1040. doi:10.1007/ s10040-015-1233-6 